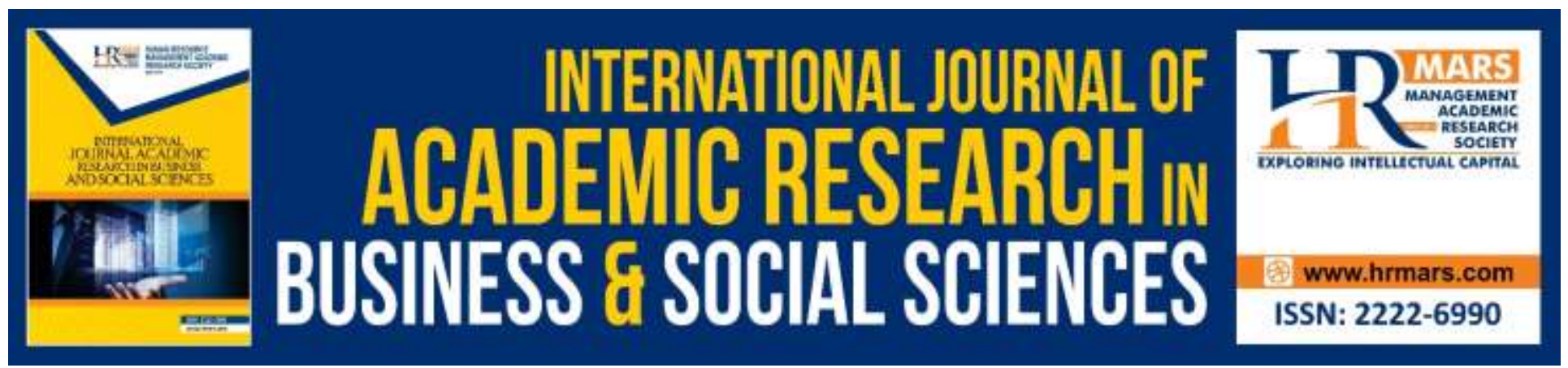

\title{
Evaluation Instrument on the Development of Interactive Multimedia Module Software: Pilot Research
}

Halimaton Shamsuddin, Che Ghani Che Kob, Noor Aida Aslinda Norizan \& A. Shah

To Link this Article: http://dx.doi.org/10.6007/IJARBSS/v9-i7/6160

DOI: $10.6007 /$ IJARBSS/v9-i7/6160

Received: 30 May 2019, Revised: 17 June 2019, Accepted: 01 July 2019

Published Online: 30 July 2019

In-Text Citation: (Shamsuddin, Kob, Norizan, \& Shah, 2019)

To Cite this Article: Shamsuddin, H., Kob, C. G. C., Norizan, N. A. A., \& Shah, A. (2019). Evaluation Instrument on the Development of Interactive Multimedia Module Software: Pilot Research. International Journal of Academic Research in Business and Social Sciences, 9(7), 686-691.

Copyright: (C) 2019 The Author(s)

Published by Human Resource Management Academic Research Society (www.hrmars.com)

This article is published under the Creative Commons Attribution (CC BY 4.0) license. Anyone may reproduce, distribute, translate and create derivative works of this article (for both commercial and non-commercial purposes), subject to full attribution to the original publication and authors. The full terms of this license may be seen at: $\underline{\text { http://creativecommons.org/licences/by/4.0/legalcode }}$

Vol. 9, No. 7, 2019, Pg. 686 - 691

http://hrmars.com/index.php/pages/detail/IJARBSS

JOURNAL HOMEPAGE

Full Terms \& Conditions of access and use can be found at http://hrmars.com/index.php/pages/detail/publication-ethics 


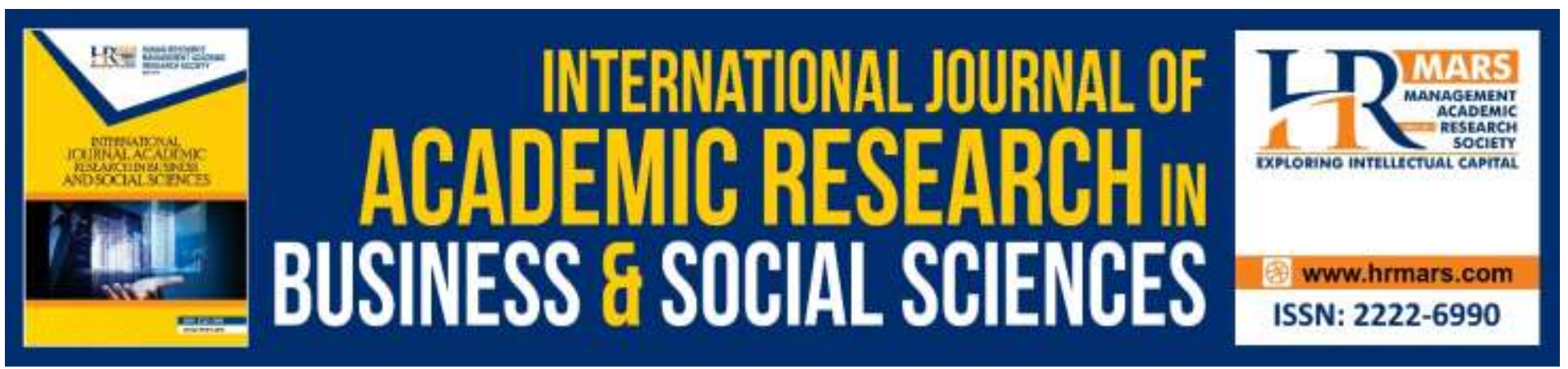

\title{
Evaluation Instrument on the Development of Interactive Multimedia Module Software: Pilot Research
}

\author{
Halimaton Shamsuddin, Che Ghani Che Kob*, Noor Aida Aslinda \\ Norizan \& A. Shah \\ Department of Engineering Technology, Faculty of Technical and Vocational, Universiti Pendidikan \\ Sultan Idris, Tanjung Malim 35900, Malaysia \\ Email: cheghani@ftv.upsi.edu.my
}

\begin{abstract}
This pilot research is carried out to verify and investigate the reliability of the instrument to evaluate interactive multimedia module software for Shielded Metal Arc Welding. This questionnaire instrument is modified by the researchers to measure the construct of the aspect, perception, content aspect, technical aspect and multimedia aspect. This instrument is made up of 66 items with Likert scale and given to 30 Welding Technology students from a Vocational College in Kelantan. In order to have a convincing reliability, researchers carry out content and face verification on the developed questionnaire. Hence, SPSS software is used to analyse the data. The results show a very high reliability of the overall construct is .96 in the Likert scale. The result of the investigation finds that 66 items can be maintained and used in evaluating the interactive multimedia module software in the real research on Malaysian Vocational College.
\end{abstract}

Keywords: Multimedia Module Software, Interactive, Shielded Metal Arc Welding, Welding Technology, Vocational College, Reliability, Pilot Research

\section{Introduction}

The application of technology in the learning and teaching especially aided by multimedia is seen to be producing a positive impact on students' achievements, whether they are from the rural or urban areas (Yazid, 2012; Shaiful et. al, 2018). There is a vast difference on education, if it was to be compared with the education from a few ages ago. This is because in the previous education system, teachers used blackboards as the medium teaching and learning. There were not a lot of teachers and educators who were able to develop their own teaching materials using technology and multimedia as a base. Most of them were using software and resources provided by the Ministry of Education. However, that has changed in the world today. Every school or academic institution in Malaysia is now equipped with computers and LCD. This shows that education in Malaysia is not left 
behind in the fast moving development in the era today. Teachers even have the ability and mastery in operating ICT and applying it in developing their own teaching material, based on technology and multimedia (Muhammad \& Bahrun, 2010; Razak \& Rahman, 2013; Rahim et.al, 2017).

The use of the technology in education will attract the attention (Sudatha et. al, 2017) and interest (Mahmood, 2016) of students. It will also enhance the students' visual and hearing senses that will help them to learn while having fun (Abdullah \& Ahmad, 2017). It is also stated by Komal et. al, (2012) in his study, 'YouTube and the expanding role of videos in Dermatologic Surgery Education'. It is stated that the use of video enables the students to understand a practical procedure with more ease as compared to reading it from academic books. Mokhtar and Rahman (2010) have also done a research on the effectiveness of the use of one of the multimedia elements in teaching and learning. The result shows that the students agree that the use of multimedia elements in the teaching and learning will increase students' interest and motivation while helping them in understanding a topic more as it could include a lot of content in one place. The use of multimedia in the teaching and learning process is very effective in leaving a deep learning in students, especially among engineering students. This is proven in the results obtained Abdullah and Ahmad (2017), along with Fatim et. al. (2014) in their studies. Students really agree on the use of multimedia in making them focus more on the learning delivered by their teachers.

\section{Research Objective}

The objective of this research is to determine the reliability of the evaluation instrument on interactive multimedia module software for Shielded Metal Arc Welding. Specifically this research is carried out to determine the value of the reliability of the instrument through the alpha coefficient analysis.

\section{Methodology Research}

Before the instrument is given out for the pilot research, it has been through a content and face validity process to look through its language aspect, structure and the words arrangement, whether they are appropriate with the components in the measurement and the meaning of the asked items (Lily et. al, 2018).

The evaluation instrument on the interactive multimedia module software for Shielded Metal Arc Welding has been piloted on 30 students of Welding Technology in three Vocational Colleges (Pengkalan Chepa Vocational College, Tanah Merah Vocational College and Kuala Krai Vocational College) in Kelantan. The questionnaire is conducted by the Leader of the Welding Technology Program in each of the Vocational College. Briefing is given to the Program Leaders involved. The respondents are chosen by the school after discussions are done with the Program Leaders. Overall, students from all three vocational colleges take 30-45 minutes to complete the questionnaires.

\section{The Reliability of the Evaluation Instrument on the Module Software Development}

Pilot study is carried out to obtain the data that can help the researchers to refine the evaluation items on the module software development before the real research is carried out. The reliability analysis is an analysis of the instrument that will be used in the research to determine the instrument 
used to measure whether a construct is accurate, consistent and reliable. In other words, a measuring tool or instrument should be tested to have a high reliability (Darusalam \& Hussin, 2016). The reliability analysis procedure has been used in the questionnaire instrument. This analysis is done to estimate the inner consistency of an instrument (Darusalam \& Hussin, 2016). This is to ensure the connecting ability is consistent between the items that form a construct in a developed instrument. In the pilot research analysis, researchers have used Alpha Cronbach value to measure the inner consistency between the items that form a construct. The Alpha Cronbach values are interpreted through the evaluation done by Bond \& Fox (2015) that includes Table 1 below. The Alpha Cronbach value score that can be accepted is 0.71-0.99, as explained by (Bond \& Fox, 2015):

Table 1: Alpha Cronbach value coefficient value interpretation

\begin{tabular}{cc}
\hline $\begin{array}{c}\text { Range of Coefficient Alpha } \\
\text { Cronbach }\end{array}$ & Reliability Strength \\
\hline $0.9-1.0$ & Very good and effective with a high consistency \\
$0.7-0.8$ & Good and can be accepted \\
$0.6-0.7$ & Can be accepted \\
$<0.6$ & Items need to be fixed \\
$<0.5$ & Items need to be dropped \\
\hline
\end{tabular}

The data obtained from the pilot research has been processed using SPSS software (Statistical Package for the Social Sciences). Researchers have used the reliability analysis instruction to obtain an alpha coefficient value for every construct and item from the overall research. Overall, the alpha value of the variable of evaluation on the module software development is $\alpha=0.96$. For a student's perception construct $\alpha=0.87$, content aspect $\alpha=0.77$, technical aspect $\alpha=0.83$ and multimedia aspect $\alpha=0.86$ (please refer to table 2).

Table 2: Alpha Coefficient value for Variable and Each Construct

\begin{tabular}{cccc}
\hline Variable / construct & Items & $\begin{array}{c}\text { Alpha } \\
\text { Coefficient }\end{array}$ & Interpretation \\
\hline Students' perception & 22 & $\alpha=0.87$ & Good and can be accepted \\
Content aspect & 10 & $\alpha=0.77$ & Good and can be accepted \\
Technical aspect & 15 & $\alpha=0.83$ & Good and can be accepted \\
Multimedia aspect & 19 & $\alpha=0.86$ & Good and can be accepted \\
\hline Total & 66 & $\alpha=0.96$ & Very good and effective with a high \\
& & & consistency \\
\hline
\end{tabular}


All four constructs (students' perception, content aspect, technical aspect and multimedia aspect) shows different alpha coefficient values. Based on the alpha coefficient values obtained by the construct, it is shown that the instrument is reliable to be used in evaluating the interactive multimedia module software for Shielded Metal Arc Welding amongst the students. This shows the reliability of the overall index is really good and effective with a high consistency because it almost reaches the value of 1.0 .

\section{Conclusion}

Hence, based on the pilot research, it can be concluded that the validity and reliability is one of the most important aspects and it should be carried out before researches are done on real respondents. Based on the SPSS analysis results that record a good item reliability index, in which the item is in the wanted construct. The results from the analysis are able to statistically prove that the items in the questionnaire have a high validity and reliability and can be used on the students from Vocational College.

\section{Acknowledgement}

The authors wish to thank the Technical and Vocational Education Division for providing the data and Universiti Pendidikan Sultan Idris (UPSI) for funding this research under 2018-0166-106-01.

\section{References}

Abdullah, S., \& Ahmad, N. S. (2017, March). Keberkesanan Aplikasi Youtube Dalam Pengajaran dan Pembelajaran Sains Kejuruteraan di Politeknik Seberang Perai. In e-Proceedings iCompEx17

Asbulah, L. H., Lubis, M. A., Aladdin, A. \& Mus'ab, S. (2018). Kesahan Dan Kebolehpercayaan Instrumen Pengetahuan Kolokasi Bahasa Arab IPT (I-KAC IPT) Menggunakan Model Pengukuran Rasch. ASEAN Comparative Education Research Journal on Islam and Civilization (ACER-J). 2(1),97-106.

Bond, T. G., \& Fox, C. M. (2015). Applying the Rasch Model Fundamental Measurement in the Human Sciences. Routledge. http://doi.org/10.1207/S15327574IJT013\&4_10

Darusalam, G. \& Hussin, S. (2016). Metodologi Penyelidikan dalam Pendidikan. Penerbit Universiti Malaya.

Hussin, F. F., Daud, M. R., \& Zakaria, S. (2014). Kajian Tinjauan Penggunaan Multimedia Pembelajaran Robotik dalam Pembelajaran dan Pengajaran. In National Innovation and Invention Competition Through Exhibition.

Koya, K. D., Bhatia, K. R., Hsu, J. T. S., \& Bhatia, A. C. (2012, September). YouTube and the Expanding Role of Videos in Dermatologic Surgery Education. Seminars in Cutaneous Medicine and Surgery.

Mahmood, H. (2016). Kajian penggunaan perisian sketchup terhadap peningkatan pencapaian pelajar dalam topik geometri bagi subjek matematik kejuruteraan satu (BA101). International Journal of Creative Future and Heritage (TENIAT), 4(1), 99-108.

Mokhtar, N., \& Rahman, N. A. A. (2010). Kajian Keberkesanan Penggunaan Video P \& P Bertajuk Proses Rawatan Air bagi Pelajar Semester Sesi Disember 2010 di Politeknik Port Dickson. Jabatan Kejuruteraan Awam Politeknik Port Dickson. 
INTERNATIONAL JOURNAL OF ACADEMIC RESEARCH IN BUSINESS AND SOCIAL SCIENCES

Vol. 9, No. 7, July, 2019, E-ISSN: 2222-6990 ¿ 2019 HRMARS

Muhammad, A., Bahrun, S. M. (2010). Persediaan Guru Pelatih Pendidikan Islam Universiti Teknologi Malaysia (UTM) Bagi Memenuhi Modal Insan. Skudai, Johor: UTM.Academic Paper.

Norajoa, S. S., Basri, Z. M., \& Latif, M. H. A. (2018). Keberkesanan Alat Bantu Mengajar "Perform Visual Inspection on Welded Joint" Dalam Pengajaran Dan Pembelajaran Teknologi Kimpalan. eProceedings National Innovation and Invention Competition Through Exhibition (iCompEx'18).

Rahim, R. H. B. A., \& Ahmad, N. B. (2017).Pembangunan E-Learning Menggunakan Perisian I-Spring Bagi

BC301 Visual Programming Di Politeknik Kota Kinabalu. International Journal of Research in Engineering and Science (IJRES).

Razak, R. A., \& Maryam, A. R. (2013). Pembinaan media pengajaran berasaskan multimedia dalam kalangan guru ICTL. Jurnal Kurikulum \& Pengajaran Asia Pasifik, Bil 1(2), 20-31.

Sudatha, W. I. G., Degeng, S. I. N., \& Kamdi, W. (2017). Developing Dynamic Visualization Multimedia on Transportation and Excretion System of Organisms Subject. International Journal of Academic Research in Business and Social Sciences, 7(10), 93-99.

Yazid, M. (2012).Keberkesanan Penggunaan Perisian Google Sketch-Up Terhadap Peningkatan Pencapaian Dan Minat Pelajar Dalam Subtopik Lukisan Unjuran Ortografik Tingkatan Dua. Prosiding ke 194 Persidangan Kebangsaan Penyelidikan Dan Inovasi Dalam Sistem Pendidikan Dan Latihan Teknikal Dan Vokasional 2012, Politeknik Nilai Negeri Sembilan, 25-26 Sept 2012. 